Ousseynou SY

Sahel University

Dakar, Senegal

ousseynou2002@gmail.com

\title{
TONI MORRISON AND RALPH ELLISON'S ORALITURE: WRITING FICTION AGAINST THE GRAIN
}

\author{
"But then life always makes you choose between two \\ possibilities, and you always feel: One is missing! \\ Always one - the uninvented third possibility!" \\ Robert Musil, The Enthusiasts
}

Recommended Citation: Sy, Ousseynou. "Toni Morrison and Ralph Ellison's Oraliture: Writing Fiction against the Grain.” Metacritic Journal for Comparative Studies and Theory 5.1 (2019): https://doi.org/10.24193/mjcst.2019.7.07

Abstract: This paper attempts to demonstrate how Ellison and Morrison's prose is interwoven with markers of oral literature, oraliture or orature. This oraliture draws upon African culture. To better deconstruct the Africanism or the different fragments of African culture in the fiction of the two writers under study, I focus on Henry Louis Gates's The Signifying Monkey and Jennings' Toni Morrison and the Idea of Africa. For example, fairy tales, the sermons of Homer Barbee and the Jazz music of Louis Armstrong, are powerful elements of oraliture which aesthetically hybridize the novelistic discourse. This oraliture becomes a revitalizing mechanism through which Ellison and Morrison subvert not only the Eurocentric aesthetic novelistic tradition but also convey their own political agenda, which represents a call for a more democratic society in a white structured world. Africanism functions, then, as a poetics of visibility that offers to Ellison and Morrison a parallel discursive arena wherein they can question historiography and invent and circulate a counterdiscourse to represent themselves and express their concerns and identities. The oraliture is not subordinate to the novelistic discourse, but rather grafts itself on the latter as an aesthetically and politically loaded counterpart. 
Keywords: Eurocentric, Africanism, oraliture, subvert, counterdiscourse, historiography, orature, visibility

A close deconstructive reading of Toni Morrison and Ralph Ellison's oral prose forms in light of what Henry Louis Gates terms "signifying" shows that Morrison and Ellison draw on African culture. Besides Gates's The Signifying Monkey: A Theory of African-American Literary Criticism, another work that can contribute to a better deconstruction of the elements of African culture and tradition is La Vinia Delois Jennings' Toni Morrison and the Idea of Africa. In her book, Jennings explains that there is a West African collective worldview that informs Morrison's work, which she calls "African retention". The sermons of Homer Barbee and Reverend Hickman, the Jazz music of Louis Armstrong, as well as the fairy tales show that the exclusion of Invisible Man and Beloved's community has given rise to countervalues of resistance. In brief, when pieced together, the different sermons of reverends in Morrison and Ellison's fictions reveal a culture of orature or oraliture; and above all most Reverends are modeled after the image of a West African griot. These cultural survival forms with which Ellison and Morrison craft their resistance and counter-memory discourse can be read as a politics of visibility set against the politics and process of otherization and carcerality that render the blacks invisible in the mainstream American culture. In both Ellison and Morrison's narratives, the forms act upon the theme. Their use of oral forms chokes and alienates the eurocentric division of genre. And this tentatively mimics the alienation of blacks in America. As a minority community, their life is hemmed in by some social power structure that the writers endeavor to break off. Not only are Ellison and Morrison's characters deprived of identity, but they also lack a social space and agency. They produce a subversive discourse that is reflected in the narrative thread, theme, language, and rhetorical devices. For example, elements of magic realism characterize the return of Beloved. Morrison's intention to subvert the eurocentric novelistic discourse is made clear when she writes in her essay "Rootedness: The Ancestor as Foundation": "I try to incorporate into that genre, the novel, unorthodox novelistic characteristics so that it is in my view Black, because it uses the characteristics of Black art" (342). The same unorthodox novelistic characteristics are manifest in Ellison's narratives. He replaces the white aesthetic using similar devices. 
This paper identifies and analyzes the politics or tropes of visibility, and cultural forms that Ellison and Morrison use to counteract the politics of otherization and invisibility. These cultural survival forms contribute to the creation of communal identity, and at the same time function as catharsis. For example, Beloved can be read as a ndëpp patient figure. In Invisible Man, for example, Homer Barbee's sermons and Armstrong's music are models for change; they enable expressions of experience and project other ways of seeing oneself. In the same vein, in Morrison's Paradise, the speech of Reverend Richard Misner, and the sermons of Reverend Hickman in Juneteenth produce a narrative of visibility and identity formation that runs counter to the politics of censorship. Indeed, Armstrong's music and the voice of the reverends function within the narrative as an ahistoriographic discourse that endeavors to undo the mainstream American discourse of censorship represented by the historiography or received American history.

Homer Barbee and Armstrong's voices in Invisible Man function primarily as an example of what Bakhtin labels "heteroglossia" defined as a conflict of voices in a text:

As a living, socio-ideological concrete thing, as heteroglot opinion, language, for the individual consciousness, lies on the borderline between oneself and the other. The word in language is half someone else's. It becomes "one's own" only when the speaker populates it with his own intention, his own accent, when he appropriates the word, adapting it to his own semantic and expressive intention. (293)

Homer Barbee's sermon on the "Blackness of Blackness" and the blues of Armstrong open the story and appropriate respectively biblical and mainstream discourses and claim the innocence of blacks. As a trickster priest, Homer Barbee delivers a speech that challenges every fixed meaning or static definition. Quoting the Bible, a privileged discourse in western culture, Homer Barbee subverts the authority of that text to give power to blacks:

"In the beginning..."

"At the very start," they cried.

"...There was blackness...”

"Preach it..."

"...and the sun." (9) 
Homer Barbee's premise that, like the "Word," blackness gives birth and origin enables him to give humanity and dignity to blacks that slavery denies them. In this respect, Homer Barbee's sermon and the music of Armstrong complement each other. Armstrong's music emphasizes the innocence of blacks:

What did I do

To be so black

And Blue?

My only sin

Is in my skin (12)

Armstrong's voice, too, is in a Bakhtinian sense in dialogical tension with the common discourse that blacks are the inferior and doomed race, for they bear the mark of Cain. Incorporated into the prose fiction, the sermons of Homer Barbee and Armstrong's music are narratives that aim at providing a viable racial identity.

Homer Barbee's sermons reveal also a culture of orality or orature as his epic story about the Founder suggests. He constructs a mythic discourse that makes inhabitable for his community a carceral universe that would be dangerously chaotic. He spins an elaborate web of stories that binds myth, reality and history together. His epic narrative presents history as the product of a mythic consciousness that can function as a catalyst in society. For example, he succeeds through the flexibility of storytelling to mythify the Founder and erect him as a frame of reference for the young college students. He calls him "the humble carpenter of Nazareth," the "black Aristotle," and the pioneer who "has erected the scaffolding of the nation" (124). Through his epic narrative, the voice of Homer Barbee breaks, in chapter five, the continuity of the prose narrative. The beginning of his tale underscores the permeability of all boundaries and the interpenetrability of oral and written voices within the same novelistic discourse. Homer Barbee gives the reader sufficient clues to let him know that the novel he is embarked upon oscillates within a hybrid genre (orality and prose). The voice of the narrator that presents Homer Barbee before the latter takes the floor to narrate his epic shows the rupture in the prose fiction and juxtaposes the two narrative voices. Homer Barbee's opening speech then distinguishes itself from written voice as Ellison makes it clear through the juxtaposition of the two voices. Homer Barbee is the repository of oral tradition in 
Ellison's Invisible Man. There is then a conflation between orality and written discourse. This tension between orality and prose fiction appears also in Ellison's text through the disembodied voice of the Grandfather that haunts invisible man and disrupts his narration. The evocation of the oral in Ellison's written text can also be read as a marker of Africanism, or a trope of what Gates terms "signifying". A trope I define, alongside Gates's definition, as a metaphor for African cultures that crossed and survived the Middle Passage, and as synecdoche for Africa.

The role of Homer Barbee reveals a civilization underneath. Ellison, consciously or unconsciously, assigns to Homer Barbee the role of a "griot" in oral African societies. Homer Barbee's name reminds that of Homer, the great Greek poet, which strengthens the similitude between Homer Barbee and the African 'griot'. The "griot" whose role is defined by Thomas Hale, in Griots and Griottes: Masters of Words and Music, as spokesperson, exhorter, praise-singer and musician fits into the function Homer Barbee plays in the text. The potential connection between Homer Barbee and the African "griot" is further made explicit through Michael Gomez's assertion that:

Rather than looking to the African priest or diviner, it may be more beneficial to consider the role of the West African griot. After all, words were his (and at time her) prince, and their use in recalling the past for panegyric purposes a very high art. It fell to the griot to re-recreate the past, or whatever the subject of his dissertation, in such a way as to make the past present, to make it palpable, to place the listener within the framework of the text. A griot's reputation rose or fell commensurate with his ability to make the story come alive (280).

Homer Barbee's mythic narrative about the Founder presents all these tropes and characteristics of a "griot". His epic sermon about the Founder has socio-cultural significance only within the context of oral tradition since it invokes the source and power of language found within that tradition. His oratorical skills enable him to praise the Founder and at the same time exhort his audience.

The dimension of exhortation and praise in the speech of Homer Barbee recalls the kañ in Wolof culture. Kañ is a type of speech that the griot formulates to drive someone to excel. In his book Parole chantée et communication sociale chez les Wolof du Sénégal, Momar Cissé describes kañ in these terms: 
The performer of kañ praises and glorifies the worker to bring him to excel. Kañ is very close to tagg which it differs from by the circumstances of production and the locative force. While tagg aims to enhance the honor and status of an individual or family to exalt his generosity or his moral rectitude, the kañ, in a jovial air, strives to make the worker of the field a man of courage and determination in the effort ... kañ may not target a specific person but a group to support them in their activities and coordinate their efforts $(156) .^{1}$

When we analyze the speeches of Homer Barbee in the socio-cultural context of social communication among the Wolof, it becomes clear that Homer Barbee uses both tagg and kañ to address his audience, the young black students. The message of kañ aims to encourage the young black people to persevere so they can make it in their incarcerated world, and that of tagg urges them to believe in themselves, their potential and their value. Moreover the stories of the Founder that Homer Barbee relates with all its characteristics of tagg and kañ are never original and always have the duty to immortalize the past and a culture. The very absence of an author illuminates the authenticity of these stories. In so doing, to use Bakhtin's term, Ellison "populates" the western genre with his own African-American identity by inscribing orality in the text. He questions then the generic division of genre between prose fiction, which sets the author as an icon, and oraliture; a genre that allows the storyteller to re-make, reform, mold, and remold the old story to make it fit to the present situations and times. Storytelling then is flexible and because of this flexibility, it has both constructive and destructive forces as Thomas King reminds us: "[Once] a story is told, it cannot be called back. Once told, it is loose in the world. So you have to be careful with the stories you tell. And you have to watch out for the stories that you are told" (10). Ellison and Morrison use these two dimensions of storytelling to question the received American history and at the same time construct their ahistoriographic discourse. Their ahistoriographic discourse wants, on the one hand, to bring to the fore the suppressed memories of slavery and its sequels

\footnotetext{
1 "Le performateur du kañ loue et glorifie le travailleur pour l'amener à se surpasser. Le kañ est très proche du tagg dont il se distingue par les circonstances de production et par la force illocutive. Pendant que le tagg vise à rehausser l'honneur et le statut d'un individu ou d'une famille pour exalter sa générosité ou sa droiture morale, le kañ, sur un air jovial, s'évertue à faire du travailleur des champs un homme de courage et de détermination dans l'effort... Le kañ peut ne pas viser une personne donnée mais tout un groupe pour le soutenir dans son activité et coordonner ses efforts" (My translation).
} 
(discrimination, segregation) and, on the other hand, claim for more political democracy in contemporary America.

Through the importance of the Founder's epic story in the narrative economy and the recurrent voice of the Grandfather, Ellison reveals the need to know how history is constructed both orally and textually. To read then the orality in the text as a mere invitation to return to oral history or a rejection of written culture is misleading. Homer Barbee's sermon is molded with spiritual notes. Like a ceremony, his sermon is designed to cure since it ends with spiritual and blues notes. The narrator writes:

They sing out their long black songs of blood and bones:

"Meaning HOPE!

"Of hardship and pain:

"Meaning FAITH!

"Of humbleness and absurdity:

"Meaning ENDURANCE!

"Of ceaseless struggle in the darkness, meaning:

“TRIUMPH.” (125-126)

Thereby, Homer Barbee turns the bitterness of his community into songs. The folkloric role of the singer that Homer Barbee performs in the end of his sermon recalls that of the "griot." As a folkloric singer, the "griot" always sings coded songs that have didactic and cathartic purposes. All these different roles that Homer Barbee embodies strengthen the idea that he is, like a "griot," a trickster. Ellison models then Homer Barbee not just on the image of a "griot," but also that of the African god, Legba. As Gates argues, Legba is a crossroads figure: he is messenger, interpreter, "lord of exchange" and above all "discourse... upon a text" (24). Like the disembodied voice of the Grandfather that breaks the continuity of the prose fiction, Homer Barbee stands for a legend through which Ellison reveals a civilization underneath. Culture is then not a fixed possession, but rather an internalized mechanism and an entire life style to the world, which has enabled the African Diasporas to preserve their cultures.

Other markers of oraliture in the two authors' fiction are the cyclical time, the folk tales and the blues. Ellison models his novel on the African conception of mythic or cyclical time. We can consider the novel as a cycle. It ends where it begins, and it is informed with a kind of thread that runs through it and holds everything together. 
The story begins with the music of Armstrong and ends with it. Similarly, the last chapter, the race riot, removes Invisible Man from time as the West conceives of it and shifts him into nonlinear and mythic time of the cultures of orality where time is compared to a crawling snake eating its own tail. Like the voice of Armstrong that contributes to the circularity of the narrative, the reflections of Invisible Man in the last chapter recreate the continuity of the past with the present. He says that "the end was in the beginning," (571) which plunges the reader into the African mythic and seasonal time, where time is conceived as an endless cycle without any clear cut beginning and ending as the yoruba metaphor of the crawling snake eating ts own tail suggests. Through his reflections, Invisible Man creates a temporal unification with the past. In one of his reflections, he brings back to the present the voice of his Grandfather and questions his advice in these terms: "My Grandfather had been wrong about yessing them to death and destruction or else things had changed too much since his day" (564). Like a fragmented self, divided between the burden of history (as symbolized by the disembodied voice of the Grandfather that haunts him and the relics of Brother Tarp he carries in his brief case), Invisible Man has to unify past and present in order to make sense of his present life. In order to enable Invisible Man to comprehend the historical forces which shape the present and confer on him a stranger within status in America, Ellison uses a circular narrative to mimic the cycles or continuity of history. Like the oral memory or orality that contrasts with the prose fiction and reveals a clash between two traditions, the cyclical time set against the western linear time carries the same tension. When Invisible Man is about to meet Emerson, he shows through his reflections how the individual's concept of time embodies a whole philosophy:

I'd have to move fast. With important men "Emerson" like that you had to be on time. If you made an appointment with one of them, you couldn't bring them any slow c.p. (colored people's) time. Yes, and I would have to get a watch. I would do everything to schedule. I recalled the heavy gold chain that hung between Dr. Bledsoe's vest pockets and the air with which he snapped his watch open to consult the time... (163)

The colored people's time that Invisible Man refers to is the nonwestern conception of time, which conceives time as immutable and flexible. Conversely, through Bledsoe's obsession with time, we can see the desire of western cultures to control time. As Bonnie Barthold argues, in "industrialized cultures," (6) the realization of the 
individual is dependent upon his mastery of time. But since Ellison draws his inspiration from the "economics of slavery" (197), as Baker reminds us, his use of cyclical time reinforces his resistance, counter-censorship, and counter-memory discourse. Instead of sanctioning the linearity of time which implies a linear history, Ellison resorts to the African communal and cyclical concept of time to revisit the archives and frame the historical process that has set the African American community apart from the linearity of time, history and progress. Indeed, it is necessary to remind here the reader that the relics of Brother Tarp like that of Bledsoe are embodiments and living memories of their community's wounded history, I mean slavery. Brother Tarp and Bledsoe bear indelible stigmas that record the unvoiced traumatic history of slavery that the Negro college trustees try to wipe out through their politics of whitewash and whitening or invisibility. For example, they purposefully build the Negro college in an old plantation so as to unmake and conceal the wounded history of African Americans.

Morrison, too, in Beloved presents time in many instances as something discontinuous, suspended, and cyclical. Denver describes Sweet Home as a place where time has stopped, or is pending, or else suspended. The sufferings that people experience linger in their minds. These experiences, like flashbacks, make them feel like living the same experience over and over again. To be psychologically sentenced to prison is to lose a sense of linear time. Displacement is another factor that makes the characters of Morrison time unconscious. To be displaced and moved around constantly make one lose a sense of linear time, as the narrator says:

It made sense for a lot of reasons because in all of Baby's life and Sethe's own, men and women were moved around like checkers. Anybody Baby Suggs knew, let alone loved, who hadn't run off or been hanged, got rented, loaned out, bought up, brought back, stored up, mortgaged, won, stole, seized (28).

The time that Baby Suggs and Sethe have been exposed to in Sweet Home is a discontinuous time, a chopped up time. Because of this constant displacement and dismemberment, the slaves developed mechanisms to keep track of time and archive their history. For example, storytelling is a means of remembering and preserving the collective memory. That is why remembering and memory are so central in Morrison's fiction. She coins the term "rememory" to emphasize the centrality of 
remembering in her craft. In fact, remembering has an ontological dimension for Morrison's characters. I can even say of Morrison's characters that they remember, therefore, they are. And rememory can only exist if the person cannot get rid off his past experiences because his present and past are blurred: they overlap. That is the case of each and every one of the main inhabitants in Sweet Home. They have been so shuffled around and traumatized like inmates that they lose grasp of the linearity and chronology of time. Rememory can be defined as a process through which the victim of a trauma internalizes and materializes his lived experience; rememory is "a picture image" as Sethe puts it. It is obvious that a people who have been constantly scattered and displaced can't keep track of time. And Morrison wants her reader to feel this experience of being constantly moved around since the reader is sent without transition from one temporal space to another. Homi Bhabha comments in his essay "The World and the Home" on this particular effect of Morrison's writing on the reader in these terms: "the reader feels snatched as the slaves were from one place to another...without preparation or defense"(146). Through Morrison's concept of rememory, we can compare Africanism to the concept of Tikkun in the Jewish tradition.

Tikkun refers to the process of restitution and healing in Jewish culture. In this respect, Adam Zachary Newton writes in Facing Black and Jew: "Tikkun, or the image of restitution has a literacy analogue in the concept of representation, a word whose very etymology signifies the bringing of something absent into presence. To this extend at least, representation turns wounds into scars, or evinces scars as signs of healing" (4). Another element of Africanism present in the two writers' fiction is rite of passage and folk songs. Set in a rite of passage, Invisible Man encounters folk tales and songs that provide a set of wise folkloric solutions to his existential crisis. In many passages, when Invisible Man is in a dilemma or duped, he hears folk songs that offer parables for his way out. In the prologue, he hears the voice of Armstrong innocently singing the trials and tribulations of blacks. In chapter nine, when he has distributed the letters of recommendation and gets no response, he meets a cartman singing a folk song that warns him about the absurdity and deceptive nature of the world he lives in. Invisible Man can't seize the parabolic meaning of this song since he is blinded by his ambition, and he is not conversant with his culture. When he meets Mr. Emerson's secretary who tells him that he should rather be an athlete than a scholar, he realizes that he has been cruelly duped. On his way home, the man next to 
him in the bus whistles a gloomy jazz song that ironically comments on his lot but he can't seize the meaning of this folk song. These folk songs, among others, in the text have didactic and therapeutic purposes. These folk songs, in particular the ones about Hare, are meant to help Invisible Man embrace his life as the segregated "other" while being fully aware of his ability to overcome his plight. He has to behave like hare or Robin or Leuk (in the Senegalese folklore) to succeed. As the cartman makes it explicit to him, "this Harlem ain't anything but a bear's den" (174). But Invisible Man can't decode the riddle as he says "I tried to think of some saying about bears to reply, but remembered only Jack the Rabbit, Jack the Bear" (174). These folk riddles about Brer Rabbit or Jack the Bear are part of the matrix of the blues to paragraph Henry Louis Gates. Hare or Rabbit, in the African-American culture, is associated with sneakiness and cleverness, which resonates deeply with the West African folk animal symbolism. For example, in the Senegalese culture, "Leuk-le-liévre" (Leuk-the Hare) stands for the sneakiest and intelligent animal in the jungle. He is a trickster feature like Brer Rabbit. In his book Léopold Sédar Senghor et Abdoulaye Sadji La belle histoire de Leuk-le-liévre, (Léopold Sédar Senghor and Abdoulaye Sadji The Beautiful story of Leuk-le-liévre), Jean-René Bourrel compiled great Senegalese folk tales written or collected by Léopold Sédar Senghor and Abdoulaye Sadji, some of which are about Leuk-le-liévre. In all the tales about Leuk-le-liévre, the latter either plays sneaky tricks on the other animals or outthinks the other animals. For example, if we take the story "The Youngest Animal" or "Le plus jeune animal" that Jean-René Bourrel mentions in his book and compare it with the tale "Brer Rabbit Fools Sis Cow" collected by the American storyteller S. E. Schlosser. There is an outstanding similitude between the two tales. When we read in juxtaposition the two tales about Brer Rabbit and Leuk-le-liévre, it becomes clear that despite the cultural framework of each tale, Leuk-le-liévre and Brer Rabbit designate the very same animal and in both cultures he stands for the trickster animal and is the most intelligent one. Besides in both folklores, he plays the same socio-cultural and didactic function. This correlation and similitude between Brer Rabbit and Leuk-le-liévre is another element of Africanism or to use Jennings' term African retention in Morrison and Ellison's fiction. Therefore, when the narrator urges Invisible Man to behave like Brer Rabbit so as to make it in his segregated world, he is using a coded message which calls upon the cultural literacy of Invisible Man. 
All these folk riddles and tales, informed by a West African collective worldview, are oral forms through which Ellison and Morrison construct both their poetics of visibility and their politics of carcerality. They use the politics of carcerality to bring to the fore the social power structure put in place to maintain a certain social hierarchy and hem in the life of African Americans. It is necessary to underline here that Ellison and Morrison's characters are often given a "stranger within" status. They are people who don't belong in. Frank Money in Morrison's Home and Invisble Man in Ellison's Invisible Man are perfect examples. And the structure of Invisible Man is, above and beneath all, built around topos of carcerality and confinement. For example, Grandfather's assumption that his community should learn to live with their "heads in the lion's mouth" (16), along with Invisible Man's claim that society refuses to see him, set the framework of imprisonment imagery. These metaphors of carcerality reveal that Ellison crafts his countermemory discourse with topos of confinement that further deny freedom and power to Invisible Man's community, and reduce them to invisibility and uniformity. The same tropes of carcerality function in Morrison's text. In Beloved, the plantation Sweet Home is reduced to a number 124 like a prison cell, and the boredom and routine of its inhabitants is very similar to that of inmates.

Also, Foucault's reflections on carcerality in Madness and Civilization allow us to think of imprisonment as a social machine, a theatre of roles, in which some people are victims and other perpetrators. In his representation, the perpetrators stand for an all powerful and rationalized institution and the "prisoners" a group of insane individuals. Foucault's metaphorics and metonymics of carcerality offer a lens through which the powerlessness, otherization, and invisibility of African Americans can be analyzed in Ellison and Morrison's fiction. By drawing on Foucault's metaphors of imprisonment, it becomes clear why most characters of Ellison and Morrison are denied the ability to act back, they become subjects, prisoners, who are only supposed to be acted upon like Jack the Bear who is always acted upon and silenced by Jack the Rabbit. And the premise of invisibility upon which Ellison builds his narrative strengthens this idea of being a passive subject.

Through their politics of carcerality, Ellison and Morrison reveal also a lack of political democracy. Indeed, if nation as a democratic institution and a social-political category is defined to be homogenous, and yet that homogeneity is constructed in terms of the whiteness of Euro-Americans, then being an African American, or even a 
Native American, implies a difference of status, a difference which the official ideologies of the American nation-state need to negotiate with. The metaphors of carcerality and invisibility that Ellison and Morrison use to show the otherization of African Americans can be read as a failure of the American nation-state to negotiate this difference. Perhaps this situation is too complex for the nation-state to solve, and therefore it adopts a mechanism of invisibility that helps to structure a white American self. In other words, the presence of African Americans and other minorities is politically important in order to represent America as a "melting pot," as a space which defines "Americanness" in terms of race inclusion. To question this race inclusion, Invisible Man utters many criticisms about nationhood and citizenship. In one of his monologues in which he ponders over the paradoxes and contradictions on which the nation is built, he says "the beautiful absurdity of their American identity and mine" (559) to contrast the democratic citizenship that other people enjoy with his carceral life.

Overall, through their politics of carcerality, Ellison and Morrison deconstruct and question the social and political system established to reduce their community to "strangers within". To claim for more visibility and equality in the mainstream American society, they turn to an exclusionary discourse, the oraliture, to help elucidate the issues of inclusion and exclusion, social justice, and the waning promise of democratic politics. Thereby, the subversion they create at the end of the day is both political and literary. The oraliture, by framing both the poetics of visibility and the politics of carcerality, functions then as a tool of subversion. The blues is another element of oraliture in the text of Ellison and Morrison.

As a tragic form, the blues functions in the text as both aesthetic and political discourse. The Mary Rambo and Clifton's scenes can be taken as examples. When Invisible Man returns from the factory hospital, Mary Rambo hosts him and sings the "Back Water Blues," which comments on both the economic situation of Mary, and exhorts Invisible Man to action. On hearing the "Back Water Blues," he realizes that he has to take the Brotherhood job offer and brings his community to visibility. He describes the effects of the Blues on him in this passage:

Then from down the hall I could hear Mary singing, her voice clear and untroubled, though she sang a troubled song. It was the "Back Water Blues." I lay listening as the 
sound flowed to and around me, bringing me a calm sense of my indebtedness. When it faded I got up and put on my coat (297).

The "Back Water Blues" that Mary sings represents more than an expression of catastrophe; it also acts as a trope for an entire process in which oral or aural expression and textual meaning complement each other. Even before Mary starts singing the blues, the narrator informs us that Mary "must be short of money" because the cabbage reminds him of "the leaner years" (296) of childhood. As a vernacular rhetoric, the blues is an oral form whose predominance in the text spills over all boundaries, enabling interference between oral and written discourse, personal and collective memory. The "Back Water Blues," like a catalyst, has the attribute of the blues that Baker defines as the ability to "conquer chaos and to master destiny" (173).

In Morrison's Beloved, too, the narrator presents in the Paul D and Hi Man escape scene a vernacular rhetoric that can 'conquer chaos and master destiny'. In the Paul D and Hi Man escape scene, Morrison puts the vernacular language which is considered as a discourse of the periphery at the center of her novelistic discourse, in so doing, she “...decenters and deforms literary language, making it appropriate for telling a blue, Black/tale" (161) as Alan J. Rice argues in her essay in Black Orpheus. Indeed, in the Paul D and Hi Man escape scene, Morrison provides a powerful example of a vernacular rhetoric that deforms the literary language. Paul D, Hi Man, and their peers are described as having the aptitude to garble "...the words so they could not be understood" and to trick "... the words so their syllables yielded up other meanings" (128). Paul D, Hi Man, and their peers through this vernacular rhetoric creates a system of communication that builds on the American language and yet is distinct from the American language. The blues that Paul D, Hi Man, and their peers sang in the escape scene is a vernacular aesthetic that allows identity formation and survival mechanism for Morrison's incarcerated community. The song that Paul D, Hi Man, and their peers are singing can be analyzed in the light of the argument of Momar Cissé that a song involves an interaction between the person who sings and his or her audience or between the people who are singing. Momar Cissé explains this interaction as follows: 
In the performance of the song, there is indeed an interlocution, that is to say an exchange. Certainly we are not here in a situation of a true dialogue where commute performance roles of transmitter and receiver, but it is a matter of oral communication in face to face situations (singer/target-listener; singer/target public) interposed, wherein each of the two entities has an influence over the other even if it is sometimes very discrete $(40) .^{2}$

In the light of Cissé's quotation, we can say that Paul D and his peers communicate through the song. That is to say, the song works in the escape scene as a language. The aptitude of Paul D, Hi Man, and the other slaves to play, manipulate, and subvert the American language to encode their own message reveals the genius and creativity of a people whose intellect was often belittled by mainstream American culture. By proselytizing the vernacular discourse, I mean by converting it into a novel discourse, Morrison not only creates an intertextuality but also deconstructs the American language. The value system of the American Eurocentric culture is repeatedly disputed by the vernacular in the text. As Paul Gilroy explains in The Black Atlantic, the blues as an element of the vernacular has formal elements, such as "improvisation," "antiphony," "intentional nonclosure" which are antithetical to an industrial society. In this respect, Gilroy writes: "Antiphony breaks down the hierarchies existent in high art forms of music where the composer and conductor hold powerful sway over their orchestras, who are forced to play the notes as written by the former and communicated by the latter" (36). The blues like the jazz works on polyrhythmic and rhythmic counterpoints that go counter to the European aesthetics. The antiphony and non-closure aspect of the blues affects the literary language in Morrison's narrative. The language that Morrison uses is discontinuous and nonlinear.

Also, as a folk expression to which all people respond, the blues contributes in the creation of a collective memory and identity. When Tod Clifton, in Invisible Man, is shot dead, the blues "Many a Thousand Gone" is sung to both mourn for him and record that event. Like an archival document, the blues "Many a Thousand Gone"

${ }_{2}$ "Dans la performance de la chanson, il y a bien une interlocution, c'est-à-dire un échange. Certes nous ne sommes pas ici dans une situation de vrai dialogue où permutent en performance des rôles d'émetteur et de récepteur, mais il est bien question de communication orale en situation de face à face (chanteur/auditeur-cible; chanteur/cible par public) interposé, où chacune de ces deux entités exerce une influence même si celle-ci est parfois très discrète sur l'autre" (My translation). 
engraves in the mind of the community the murder of Clifton. The blues "Many a Thousand Gone" collects not just tragic events, but also affirms suppressed memories, stories, and provides healing. But it is obvious that the memories the blues collects bear the marks of violence and trauma that affect the African American community. We can then read the blues as a resistance, anti-censorship and counter-memory discourse that Ellison sets against the official historiography that wants to suppress these traumatic memories. The blues "Many a Thousand Gone" is akin to the tikkun since it allows the restitution of collective memories and provides enough room for mourning and healing.

Given that memory is set against the official historiography, Ellison and Morrison present it not only as an archive that is out of reach of the received American history recorders, but also as something multidimensional. Memory appears in many a form in their narrative. A place, an object, a story, and a sound can trigger a memory. To Morrison and Ellison, plantations can provide narratives about the past like the textualized bodies or stories. Plantations just by their own presence capture the silences of history, they make a plea against amnesia: they are a metaphor for memory. But as a sound, the blues is more effective in triggering memories than plantations. Through the blues and folktales Ellison and Morrison participate in creating a collective memory. Indeed, the blues, the jazz, the folktales, and the museums of memory (plantations) are also meant to capture the composite voice of history. The folktales and the blues within the written discourse of Morrison and Ellison reinforce their political agenda. If there is a relation between narrative or linguistic fact and social ground as Jameson sustains, then Morrison and Ellison's use of the blues and slave folk tales in their act of narration inscribes manifestly their social ideology as Baker argues:

Ellison knows that his work as an Afro-American artist derives from he 'economics of slavery' that provided conditions for Afro-American folklore. Black folk expression is a product of the impoverishment of blacks in America. The blues, as a case in point, is unthinkable for those happy with their lot (197).

Therefore, there is a historical and ideological subtext in Ellison and Morrison's narratives. Whether we call it Africanism, or "African Retention," or else African American folklore, it reveals that narrative is - to use Jameson's phrase - "a socially 
symbolic act". Through the use of the blues and orality, Ellison creates a patrimony of culture that frames Invisible Man's origin, and answers the ontological question that Invisible Man raises at the beginning of the story: "And yet I am no freak of nature, nor of history" (15). And similarly, Morrison's narrative dealing thematically with the meaning and significance of home is accompanied by an Africanism that bridges home and the transplanted home. By drawing on African culture, Morrison turns Beloved into a two-faced narrative: one that looks back to slavery for finding out an inspiration, a meaning, and another one that looks ahead towards redemption and restitution. This redemption and restitution is conveyed through the medium of the oraliture, which in itself is a sort of restitution.

To overlook then the huge presence of Africanism in Ellison and Morrison's text is to narrow the scope of their scholarship. For example, drawing on magic realism, Beloved can be read as a ndëpp character. Ndëpp ceremonies in the Wolof culture are moments of magic realism because the living, the jinns, and all the ancestors participate in the ceremony. The presence of all these entities is necessary for the ceremony to be effective. Momar Cissé describes the ndëpp in these terms:

The ndëpp's approach is collective. It gathers the patient, his parents, the healer, the Ancestors and the Spirits. To reach its intented objective, which is the healing of the sick, it is essential that all these entities show up. The texts, by their content, are mainly composed of reminders of sacred names and sometimes achievements of the Ancestors. In this way, they link past, present and myths in their function to justify and perpetuate the magical-religious beliefs of Wolof society (116). 3

The ndëpp ceremony is very close to the Vodun which Jennings talks about. The ndëpp, like the Vodun, illustrates the strong presence of magic realism in African culture. The magical-religious logic embedded in the ndëpp can help us better understand the return of Beloved to her family and the close connection between the present and the past, the real and the imaginary, and the censored and the authorized within the narrative. Reading the return of Beloved through the lens of the ndëpp

\footnotetext{
3 "La démarche du ndëpp est collective. Elle rassemble le malade, ses parents, le guérisseur, les Ancêtres et les Esprits. Pour que l'objectif qui est de guérir le malade soit atteint, il faut absolument le concours de toutes ces entités. Les textes, de par leur contenu, sont essentiellement composés de rappels de noms sacrés et parfois d'exploit des Ancêtres. De cette manière, ils lient présent, passé et mythes dans leur fonction de justifier et de perpétuer les croyances magico-religieuses de la société wolof" (My translation).
} 
ceremony makes her stand for the ancestor, the spirit and the healer, and her parent (Sethe) embody the patient. The objective of Beloved's ndëpp ceremony is to heal her mother for her guilt so to speak, meaning to absolve her mother of her guilt. The ndëpp purifies the patient and cures his mental and psychological disorders. The fact that Beloved shows up in the house makes Sethe believe that the crime didn't really happen. There is then a reversed ndëpp ceremony in Beloved since the one who is supposed to be the patient is the healer. This reversal in the classic scenario of the ndëpp is meant to capture the complex nature of Beloved and the crime that she is a victim of. A crime that involves and incriminates different continents. The crime of Sethe is buried in the text; nowhere is the act of infanticide related to the reader. The reader knows mostly about the crime through the guilt of Sethe. The ndëpp ceremony is meant to wipe out this motherly guilt. This intricate relationship between the muted or censored and the spoken is central in Beloved, and it mimics at the same time the conflation between the oraliture and the written text, and the historiographic and ahistoriographic discourse.

Another dimension of the ndëpp ceremony consists in pouring blood and milk on and around the patient, this part of the ndëpp is called "tuuru" or "tuur". The passage where Sethe gives milk mixed with blood to Beloved corresponds to the "tuuru". The following dialogue between Sethe and Beloved makes relevant such an interpretation:

You are my face; I am you. Why did you leave me...

I will never leave you again

Don't ever leave me again

You will never leave me again

You went in the water

I drank your blood

I brought you milk

You forgot to smile

I love you. (256) 
The ndëpp is successful only when the patient is cured of his or her ailments and reintegrated back into the society. Indeed, the ndëpp ceremony seeks to reconcile the patient with his community, his ancestors, and spirits or jinns. The return of Beloved reconciled Sethe with her past and her family. Sethe's past and present intricately overlap, she can only make sense of her present if she embraces Beloved with all her weirdness and irrationality. Overall, the exchange of milk and blood between Sethe and Beloved, and the irrationality of Beloved are elements of magic realism that can be better comprehended through a ndëpp ceremony.

We can argue that the elements of Africanism in Ellison and Morrison's texts (orality, blues, cyclical time, magic realism, and folk tales) are intricate narrative devices that function as cultural survival forms through which the two authors under study express their plea for political democracy in a white structured society. These elements of Africanism are countervalues of resistance that prevent the death and erasure of a culture and history. And at the same time by fusing their narratives with oral and aural forms, Ellison and Morrison question the Eurocentric division of genre. The blues and the jazz are the aural symbols of the African-American identity; they are a sort of national anthem or hymn for the American black community. Not only do they archive the history of the community but also they allow the creation of a communal identity and collective memory. Then, through a sophisticated interwoven prose and oral form, Morrison and Ellison subvert the novelistic discourse so as to create an ultra-responsive narrative of visibility that presses against the censorship of memory and the ahistoriographic discourse they relate. Morrison and Ellison's oraliture is alien to but not inferior to the novelist discourse; their oraliture has shown that difference is not synonymous with deficiency. Indeed, their oraliture is aesthetically well grafted onto the novelistic discourse, and thereby they have invented "the uninvented third possibility", to echo Robert Musil's opening epigraph, by creating a social and aesthetic subversion with the very same tool. This "uninvented third possibility" is also an attempt to decolonize the production and consumption of knowledge in literary studies. Indeed, the oraliture is grounded on specific ontologies and epistemes that are outside of the framework of western canonized knowledge. 


\section{References:}

Baker, Houston A., Jr. Blues, Ideology, and African American Literature, A Vernacular Theory. The University of Chicago Press, 1984.

Bakhtin, M. Mikhailovich. The Dialogic Imagination: Four Essays by Bakhtin, edited by Michael Holquist (translated by Caryl Emerson \& Michael Holquist). University of Texas Press, 1981.

Barthold, Bonnie J. Black Time: Fiction of Africa, the Caribbean and the United States. Yale University Press, 1981.

Bourrel, Jean-René (editor). Léopold Sédar Senghor et Abdoulaye Sadji La belle histoire de Leuk-le-liévre. Éditions Sépia, 2008.

Cissé, Momar. Parole chantée et communication sociale chez les Wolof du Sénégal. L'Harmattan, 2009.

Ellison, Ralph. Invisible Man. Vintage International, 1990.

---. Juneteenth, edited by J.F. Callahan. Hamish Hamilton, 1999.

Foucault, Michel. Madness and Civilization: A History of Insanity in the Age of Reason. Vintage, New York. 1988.

Morrison, Toni. Beloved. Vintage International: Vintage Books, Random House, Inc., 2004.

Saadi, A. Simawe (editor). Black Orpheus: Music in African-American Fiction from the Harlem Renaissance to Toni Morrison. Garland Publishing, Taylor and Francis Group, 2000.

Bhabba, Homi. "The World and the Home." Third World and Post-colonial Issues, Number 31-32, 1992.

Newton, Adam Zachary. Facing Black and Jew: Literature as Public Space in Twentieth- Century America. Cambridge University Press, 1999.

Gates, Henry Louis, Jr. The Signifying Monkey: A Theory of African-American Literary Criticism. Oxford University Press, 1988.

Gomez, Michael A. Exchanging Our Country Marks: The Transformation of African Identities in the Colonial and Antebellum South. The University of North Carolina Press, 1998.

Hale, A. Thomas. Griots and Griottes: Masters of Words and Music. Indiana University Press, 1998.

Jameson, Fredric. The Political Unconscious: Narrative as a Socially Symbolic Act. Cornell University Press, 1982. 
King, Thomas. The Truth About Stories: A Native Narrative. University of Minnesota Press, 2005.

Reiter, Bernd (editor). Constructing the Pluriverse: The Geopolitics of Knowledge. Duke University Press, 2018. 